\title{
Energy and economic sustainability in the renewal of centralized heating systems using hybrid heat pump systems
}

\author{
Federico Tomas ${ }^{1, *}$ and Alberto Dal Cason ${ }^{2}$ \\ ${ }^{1}$ Baxi S.p.A., Product Manager - Heat Pumps, Bassano del Grappa (VI), Italy \\ ${ }^{2}$ Baxi S.p.A., Head of Product Managers, Bassano del Grappa (VI), Italy
}

\begin{abstract}
In the context of the energy transition policies desired by the EU, the objectives set by 2030 include the reduction of greenhouse gas emissions, the achievement of greater energy savings and the increase in the use of renewable energy. This study, after an analysis concerning the Italian building stock, aims to highlight a possible first step towards achieving these objectives: the renewal of centralized heating systems in multi-dwelling buildings. In fact, on the national scenario there are about 430,000 condominiums with centralized heating system built before 1990 and, therefore, possibly liable to energy efficiency. In this research a case study building was simulated using the software EnergyPlus in which a renovation of the existing heating system was modelled in the Matlab/Simulink environment with an innovative hybrid generator consisting of an air/water heat pump and a condensing boiler. The analysis of this solution, carried out for three different Italian climatic zones, highlights how significant reductions in $\mathrm{CO}_{2}$ emissions can be achieved, high energy savings in terms of primary energy use and savings regarding usage costs, thus achieving greater comfort and sustainability. In addition, an economic analysis was carried out comparing different combinations of systems with the aim of identifying the best solution for each application.
\end{abstract}

\section{Summary}

This study aims to investigate the renewal of thermal power plants in multi-dwelling residential buildings with a view to achieving the goals set by the European Union in the field of energy performance in buildings (Directive (EU) 2018/844).

An analysis of the Italian building stock shows that, in the national scenario, there are about 430,000 multi-dwelling buildings with centralized heating systems built before 1990 and, therefore, possibly subject to energy efficiency. This study analyses the energy optimization of a centralized heating system, using as a generator, a hybrid system consisting of an air/water heat pump and a condensing boiler, in multi-dwelling buildings. For this reason, a case-study building consisting of ten apartments, and inhabited by thirty people, has been modelled with an envelope from the 1960s, not thermally insulated. The same building was

\footnotetext{
*Corresponding author: federico.tomas@,baxi.it
} 
then simulated dynamically on an hourly basis, using the OpenStudio and EnergyPlus software, in two different Italian climatic zones: Milan and Rome.

Once the energy needs and external air conditions in the two climatic zones have been identified, a block diagram was designed in a Matlab/Simulink environment that describes the behavior of the hybrid system. To do this, the two generators have been modelled using polynomial functions that implement the real operating data of the thermal machines considered. The operation of the hybrid generator was simulated, in each case, with two different types of terminals: high temperature $\left(\mathrm{T}_{\max }=70{ }^{\circ} \mathrm{C}\right)$ and low temperature $\left(\mathrm{T}_{\max }=40{ }^{\circ} \mathrm{C}\right)$. The regulation of the delivery temperature was determined through appropriate climatic curves in order to further improve energy efficiency at partial loads (delivery temperature as a function of the external temperature).

After collecting the results from the block diagram, an energy analysis was carried out to find the most efficient and, at the same time, more sustainable solution for each case treated. Finally, was performed an economic analysis of the investment. To do this, various economic indices were evaluated, including: Net Present Value (NPV), Internal Rate of Return (IRR), Payback Period and Daily Cost considering the discounting of costs.

The results show that are achieved significant reductions in $\mathrm{CO}_{2}$ emissions, high energy savings in terms of primary energy use and savings regarding the utilization costs, thus achieving greater sustainability. In addition, the economic analysis certifies that there is significant reduction in the initial investment (compared to a stand-alone heat pump) and reduced payback times thanks to the actual Italian incentive (Ecobonus 65\% or Superbonus $110 \%$ ).

\section{Introduction}

As part of the energy transition policies desired by the European Union, the current strategic program is determined based on the global integrated climate and energy policy adopted by the European Council on $24^{\text {th }}$ October 2014 and revised in December 2018, which provides for the achievement of the following goals by 2030 :

- Reduce greenhouse gas emissions by $40 \%$ compared to 1990 levels;

- Increase the share of renewable energy in energy consumption to $32 \%$;

- Improve energy efficiency to $32.5 \%$.

The revised directive on the energy performance of buildings (Directive (EU) 2018/844) establishes roadmaps with indicative milestones for 2030, 2040 and 2050 and long-term strategies to enable Member States to support park renovation of residential and nonresidential buildings, both public and private, in order to achieve an energy-efficient and decarbonized building stock by 2050 . In October 2020, the Commission published the new strategy on the wave of renovations (COM 2020/662) which aims to double annual energy renovation rates over the next ten years.

This study, after an analysis concerning the Italian building stock, aims to highlight a possible first step to achieve these objectives: the renewal of thermal power plants in multi-dwelling buildings. In the national scenario there are about 430,000 multi-dwelling buildings with centralized heating systems built before 1990 and, therefore, possibly subject to energy efficiency.

In this research a case study building was modelled, in which a renewal of the thermal power plant was hypothesized where an innovative hybrid generator, consisting of an air/water heat pump and condensing boiler, replaces a standard efficiency boiler. 


\section{Analysis of residential buildings in Italy}

In order to characterize the Italian residential buildings stock, the data resulting from the $15^{\text {th }}$ Italian census, collected by the National Statistical Institute (ISTAT) in 2011 [1], have been analysed, to divide the existing buildings on the basis of:

- Year of construction;

- Geographical distribution of the considered buildings;

- Average number of dwellings per building;

- Type of heating system installed.

Each of the categories listed has been evaluated for five different Italian geographical areas: Northeast, Northwest, Center, South and Islands.

Table 1 shows the results that emerged from the data analysis, while Table 2 shows the percentage distribution of the years of construction of the considered residential buildings:

Table 1. Geographical distribution and absolute values of residential buildings, with centralized heating system, with 5 or more dwellings.

\begin{tabular}{|l|c|}
\hline $\begin{array}{c}\text { Buildings, with centralized heating } \\
\text { system, with } 5 \text { or more dwellings }\end{array}$ \\
\hline Northeast & 94,054 \\
\hline Northwest & 240,395 \\
\hline Center & 98,338 \\
\hline South & 46,531 \\
\hline Islands & 21,134 \\
\hline ITALY & $\mathbf{5 0 0 , 4 5 2}$ \\
\hline
\end{tabular}

Table 2. Percentage distribution of the years of construction of the considered residential buildings.

\begin{tabular}{|l|c|}
\hline $\begin{array}{c}\text { Years of construction of residential } \\
\text { buildings - percentages }\end{array}$ \\
\hline Before 1946 & $25.9 \%$ \\
\hline $1990-1946$ & $60.2 \%$ \\
\hline $2000-1991$ & $7.1 \%$ \\
\hline After 2000 & $6.8 \%$ \\
\hline
\end{tabular}

Multiplying the data in Tab. 1 by the percentage distribution in Tab. 2, we obtain that in Italy there are 430,889 multi-dwelling buildings built before $1990,48 \%$ of them are located in the Northwest area.

\section{Model of the case study building and simulation in dynamic regime}

Moving on to the case study, a building consisting of 10 apartments, distributed over 5 floors, has been modelled using 3D modelling software. Once we created the building model, through the OpenStudio plug-in (Energy Plus user-friendly interface), we defined the thermal zones, whose behavior was then studied using the software mentioned above.
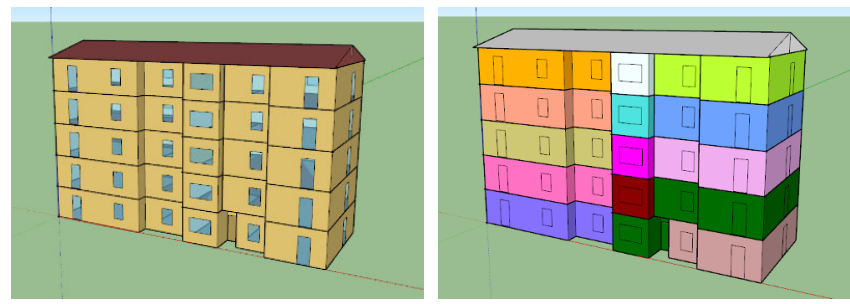

Fig. 1. 3D model of the building and division into thermal zones. 
Once the envelope of the building has been defined, the following characteristics have been defined in OpenStudio:

- Internal loads (internal mass, air infiltration, electrical equipment, ...);

- Weather file;

- Features of the loads (Schedules);

- Stratigraphy.

The data and materials characterizing the stratigraphy were defined by the Piacenza Energy \& Environment Laboratory (LEAP) and describe the typical envelope of a 1960 building, resulting not thermally insulated [2].

The software allows to simulate the behaviour in dynamic regime, on an hourly basis, of the modelled building. In the considered heating period $\left(15^{\text {th }}\right.$ October $-15^{\text {th }}$ April), we obtain the following values of energy demand and peak power:

Table 3. Values of energy needs and peak power, in the heating period, for the two considered cities.

\begin{tabular}{|l|c|c|}
\hline \multicolumn{1}{|c|}{ CITY } & $\begin{array}{c}\text { ENERGY DEMAND } \\
{[\mathbf{k W h}]}\end{array}$ & PEAK POWER [kW] \\
\hline Milan & $98,624.97$ & 61.41 \\
\hline Rome & $45,114.23$ & 51.31 \\
\hline
\end{tabular}

The distribution of energy needs, depending on the external air temperature, is:

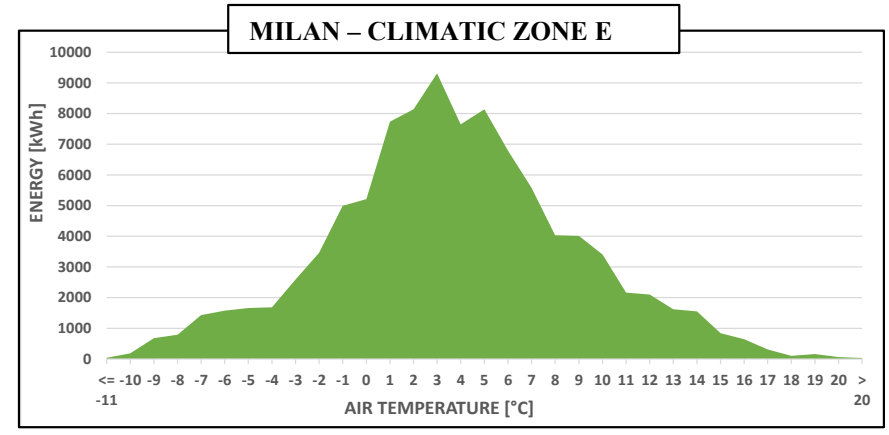

Fig. 2. Distribution of energy needs $[\mathrm{kWh}]$ as a function of the outside air temperature $\left[{ }^{\circ} \mathrm{C}\right]-$ Milan.

The peak value, regarding the energy demand, stands at $9,312.80 \mathrm{kWh}$, which corresponds to an external temperature of $3{ }^{\circ} \mathrm{C}$. The interval between $-1{ }^{\circ} \mathrm{C}$ and $6{ }^{\circ} \mathrm{C}$ corresponds to an energy demand of $57,953.84 \mathrm{kWh}$, equal to $58.8 \%$ of the total. 


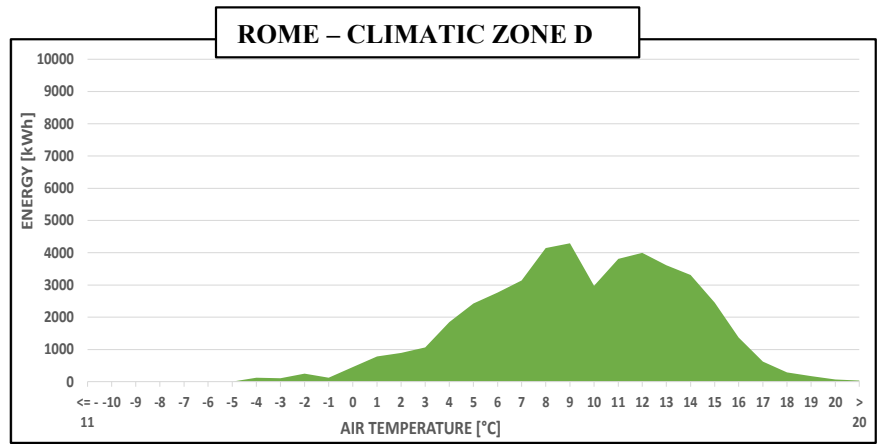

Fig. 3. Distribution of energy needs $[\mathrm{kWh}]$ as a function of the outside air temperature $\left[{ }^{\circ} \mathrm{C}\right]-$ Rome.

The peak value stands at $4,293.46 \mathrm{kWh}$, which corresponds to an external temperature of $9{ }^{\circ} \mathrm{C}$. The interval between $7{ }^{\circ} \mathrm{C}$ and $14{ }^{\circ} \mathrm{C}$ corresponds to an energy demand of $29,283.41$ $\mathrm{kWh}$, equal to $64.9 \%$ of the total. This fact highlights how the climate is warmer than in the previous case.

\section{Hybrid system model in Matlab/Simulink environment}

After defining the case study, a block diagram has been created in the Matlab/Simulink environment that describes the operation of the hybrid generator consisting of:

1. Baxi PBM2-i heat pump, air/water with power modulation (inverter), R410A refrigerant;

2. Baxi Luna Duo-Tec MP+ condensing boiler.

In addition to the two generators described above, has been simulated the presence of a thermal storage tank (500 liters).

The block diagram consists of seven groups that describe the following variables:

- Delivery temperature (climatic curve);

- Full load power of the heat pump;

- Operating limits, in heating, of the heat pump;

- Electric power absorbed by the heat pump;

- Thermal losses of the storage tank;

- Boiler efficiency;

- System operating logics.

The operation of the generators has been implemented through polynomial functions, obtained from the real operating data of the considered machines:

- Thermal power supplied (1) and electrical power absorbed (2) by the heat pump $[\mathrm{kW}]$ :

$$
\begin{aligned}
& P_{t, h p}=f\left(T_{\text {ext }}, T_{d}, Q_{\text {building }}\right) \\
& P_{e, h p}=f\left(T_{\text {ext }}, T_{d}, Q_{\text {building }}\right)
\end{aligned}
$$

- Boiler efficiency (3) and hourly volume of natural gas used $\left[\mathrm{Sm}^{3}\right](4)$ : 


$$
\begin{gathered}
\eta_{t, b}=f\left(T_{d}\right) \\
V_{\text {gas }}=\frac{P_{t, b}}{\eta_{t, b} \cdot L H V_{\text {gas }}}
\end{gathered}
$$

- Hourly heat losses of the storage tank [kWh]:

$$
Q_{\text {loss }}=K \cdot S \cdot \Delta T
$$

Where: $\mathrm{T}_{\text {ext }}=$ outside air temperature $\left[{ }^{\circ} \mathrm{C}\right]$

$\mathrm{T}_{\mathrm{d}}=$ delivery temperature $\left[{ }^{\circ} \mathrm{C}\right]$

$\mathrm{Q}_{\text {building }}=$ energy demand of the building

$\mathrm{P}_{\mathrm{t}, \mathrm{b}}=$ thermal power supplied by the boiler $[\mathrm{kW}]$

$\mathrm{LHV}_{\text {gas }}=$ lower calorific value of natural gas $\left[\mathrm{kWh} / \mathrm{Sm}^{3}\right]$

$\mathrm{K}=$ heat transfer coefficient $=0.002\left[\mathrm{~kW} / \mathrm{m}^{2} \mathrm{~K}\right]$

$\mathrm{S}=$ surface function of the storage geometry

$\Delta \mathrm{T}=$ temperature difference $=\mathrm{T}_{\text {storage }}-\mathrm{T}_{\text {ext,storage }}$

The operation of the hybrid generator has been simulated through the integration logic of the Baxi Hybrid Power system: the heat pump has the priority of intervention, while the boiler integrates when the heat pump does not satisfy the entire load or when the demand of the system exceeds its operating limits. Furthermore, it was considered that both generators are able to modulate the power supplied according to the real behavior of the products. The data deriving from the hourly simulation were collected in a database, to allow the desired analysis to be implemented.

The hybrid system was simulated considering different generator sizes:

Table 4. Combinations between the powers of the generators.

\begin{tabular}{|l|c|c|c|c|c|c|}
\hline \multirow{2}{*}{ CITY } & \multicolumn{2}{|c|}{ COMBINATION 1 } & \multicolumn{2}{c|}{ COMBINATION 2 } & \multicolumn{2}{c|}{ COMBINATION 3 } \\
\cline { 2 - 7 } & HP & Boiler & HP & Boiler & HP & Boiler \\
\hline Milan & $20 \mathrm{~kW}$ & $70 \mathrm{~kW}$ & $35 \mathrm{~kW}$ & $70 \mathrm{~kW}$ & $42 \mathrm{~kW}$ & $90 \mathrm{~kW}$ \\
\hline Rome & $20 \mathrm{~kW}$ & $60 \mathrm{~kW}$ & $25 \mathrm{~kW}$ & $60 \mathrm{~kW}$ & $35 \mathrm{~kW}$ & $70 \mathrm{~kW}$ \\
\hline
\end{tabular}

The sizes described have been chosen in such a way that the boiler can always supply peak demands and the ratio between the power of the heat pump and the power of the boiler is always $\leq 0.5$, fundamental condition for accessing the incentive Superbonus $110 \%$.

\section{Data analysis: energy optimization}

The following parameters have been calculated for each simulated city and hybrid system combination:

- Fraction of the energy demand covered by the two generators;

- Use of primary energy, considering the following conversion factors (UNI/TS 11300) $[3,4]$ :

Table 5. Primary energy conversion factors (excluding transport).

\begin{tabular}{|l|c|}
\hline \multicolumn{1}{|c|}{ Energy Vector $[\mathbf{k W h}]$} & Conversion Factor \\
\hline Electricity (from the grid) & 2.174 \\
\hline Natural Gas & 1.00 \\
\hline
\end{tabular}


- Carbon dioxide emissions $\left(\mathrm{CO}_{2}\right)$, considering the following emission factors:

Table 6. Carbon dioxide emission factors.

\begin{tabular}{|l|c|}
\hline \multicolumn{1}{|c|}{ Energy Vector $[\mathbf{k W h}]$} & Emission Factor $\left[\mathbf{k g} \mathbf{C O}_{2} / \mathbf{k W h}\right]$ \\
\hline Electricity (from the grid) & 0.4332 \\
\hline Natural Gas & 0.1998 \\
\hline
\end{tabular}

- Annual utilization costs, considering the following unit costs:

Table 7. Unit costs.

\begin{tabular}{|l|c|c|}
\hline \multicolumn{1}{|c|}{ Energy Vector $[\mathbf{k W h}]$} & Unit & Unit Cost \\
\hline Electricity (from the grid) & $€ / \mathrm{kWh}$ & 0.20 \\
\hline Natural Gas & $€ / / \mathrm{Sm}^{3}$ & 0.80 \\
\hline
\end{tabular}

These quantities have been compared with the ones resulting from the utilization of a standard efficiency boiler, in order to quantify the savings achievable in the case of renewal of the thermal plant, where the obsolete generator is installed.

The results obtained for each city, system combination and type of plant terminals are shown below:

\section{Milan (Climatic Zone E) - High Temperature Terminals}

The utilities are served by a variable flow temperature according to the external temperature. The hypothesis is to provide the terminals with the $\mathrm{T}_{\text {design }}$ temperature equal to $70{ }^{\circ} \mathrm{C}$ and a $\mathrm{T}_{\min }$ equal to $50^{\circ} \mathrm{C}$.

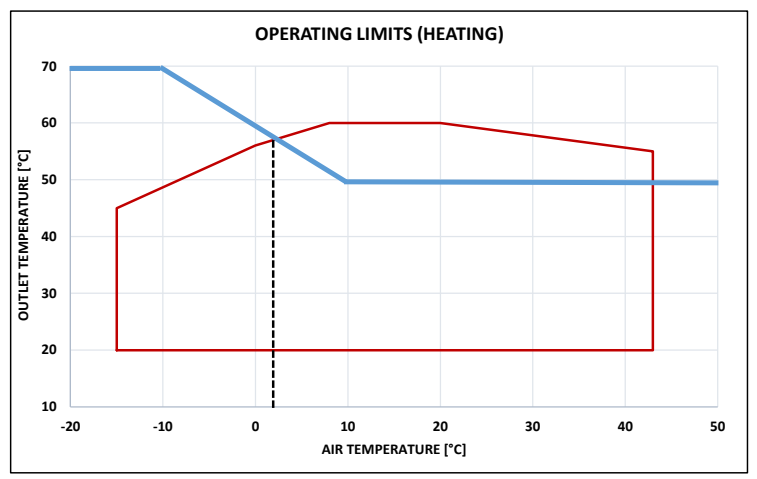

Fig. 4. Operating limits, in heating, of the heat pump and high temperature climatic curve.

Deepening the topic of regulation of the temperature supplied to the system through a climatic curve, in Fig. 4 the climatic curve $T_{\mathrm{d}}=f\left(T_{e x t}\right)$ is shown in blue and the operating limits of the heat pump in red. In these conditions the heat pump will only be able to work in a limited operating range due to the high delivery temperatures. The intersection between the two curves allows to identify the $T_{\text {cut-off }}$ of this generator. 
Table 8. Environmental aspects, high temperature plant - Milan.

\begin{tabular}{|c|c|c|c|c|c|}
\hline \multirow[b]{2}{*}{ Parameters } & \multirow[b]{2}{*}{ Generator } & \multirow[b]{2}{*}{ Unit } & \multicolumn{3}{|c|}{ GENERATORS } \\
\hline & & & $\begin{array}{c}\text { HP } 20 \mathrm{~kW} \\
\text { BOILER } 70 \mathrm{~kW}\end{array}$ & $\begin{array}{c}\text { HP } 35 \mathrm{~kW} \\
\text { BOILER } 70 \mathrm{~kW}\end{array}$ & $\begin{array}{c}\text { HP } 42 \mathrm{~kW} \\
\text { BOILER } 90 \mathrm{~kW}\end{array}$ \\
\hline \multirow{3}{*}{ Primary energy } & HP & \multirow{3}{*}{$\mathrm{kWh}$} & 21862,39 & 29192,89 & 30859,51 \\
\hline & BOILER & & 64121,58 & 51753,14 & 48993,76 \\
\hline & TOTAL & & 85983,97 & 80946,03 & 79853,28 \\
\hline \multirow{3}{*}{$\mathrm{CO}_{2}$ emissions } & HP & \multirow{3}{*}{$\mathrm{kg}_{\mathrm{CO} 2}$} & 4356,39 & 5817,09 & 6149,19 \\
\hline & BOILER & & 12811,49 & 10340,28 & 9788,95 \\
\hline & TOTAL & & 17167,88 & 16157,37 & 15938,15 \\
\hline
\end{tabular}

Table 9. Operational aspects, high temperature plant - Milan.

\begin{tabular}{|c|c|c|c|c|}
\hline \multirow[b]{2}{*}{ Parameters } & \multirow[b]{2}{*}{ Unit } & \multicolumn{3}{|c|}{ GENERATORS } \\
\hline & & $\begin{array}{c}\text { HP } 20 \mathrm{~kW} \\
\text { BOILER } 70 \mathrm{~kW}\end{array}$ & $\begin{array}{c}\text { HP } 35 \mathrm{~kW} \\
\text { BOILER } 70 \mathrm{~kW}\end{array}$ & $\begin{array}{c}\text { HP } 42 \mathrm{~kW} \\
\text { BOILER } 90 \mathrm{~kW}\end{array}$ \\
\hline Energy demand & kWh & \multicolumn{3}{|c|}{98624,97} \\
\hline \multirow{2}{*}{ Energy provided - HP } & kWh & 37167,20 & 49337,13 & 52039,47 \\
\hline & $\%$ & $37,69 \%$ & $50,02 \%$ & $52,76 \%$ \\
\hline \multirow{2}{*}{ Energy provided - Boiler } & $\mathrm{kWh}$ & 61457,77 & 49287,84 & 46585,51 \\
\hline & $\%$ & $62,31 \%$ & $49,98 \%$ & $47,24 \%$ \\
\hline \multirow{2}{*}{ Electricity absorbed - HP } & kWh & 10056,29 & 13428,19 & 14194,81 \\
\hline & $€$ & 2011,26 & 2685,64 & 2838,96 \\
\hline \multirow{3}{*}{ Natural gas - Boiler } & $\mathrm{Sm}^{3}$ & 5983,95 & 4829,70 & 4572,19 \\
\hline & kWh & 64121,58 & 51753,14 & 48993,76 \\
\hline & $€$ & 4787,16 & 3863,76 & 3657,75 \\
\hline Usage cost & $€$ & 6798,42 & 6549,40 & 6496,71 \\
\hline
\end{tabular}

The energy demand of the building covered by the $20 \mathrm{~kW}$ heat pump is equal to $37.7 \%$, while in the system with a $35 \mathrm{~kW}$ heat pump the satisfied fraction rises to $50.0 \%$, up to $52.8 \%$ considering the larger size of this generator, $42 \mathrm{~kW}$.

The coverage of the heat pump can never be total due to the temperatures required by the system that exceed the operating range of the unit.

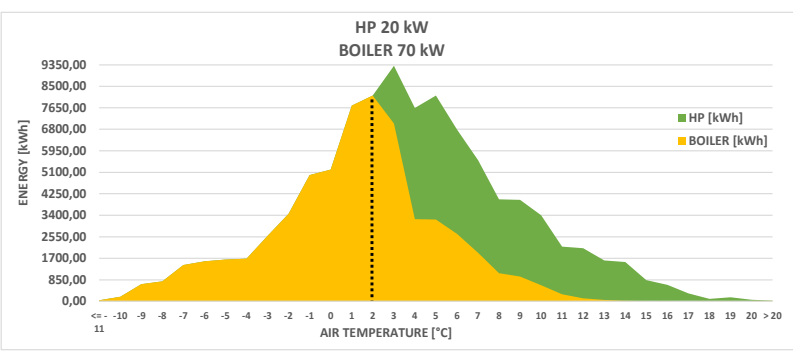




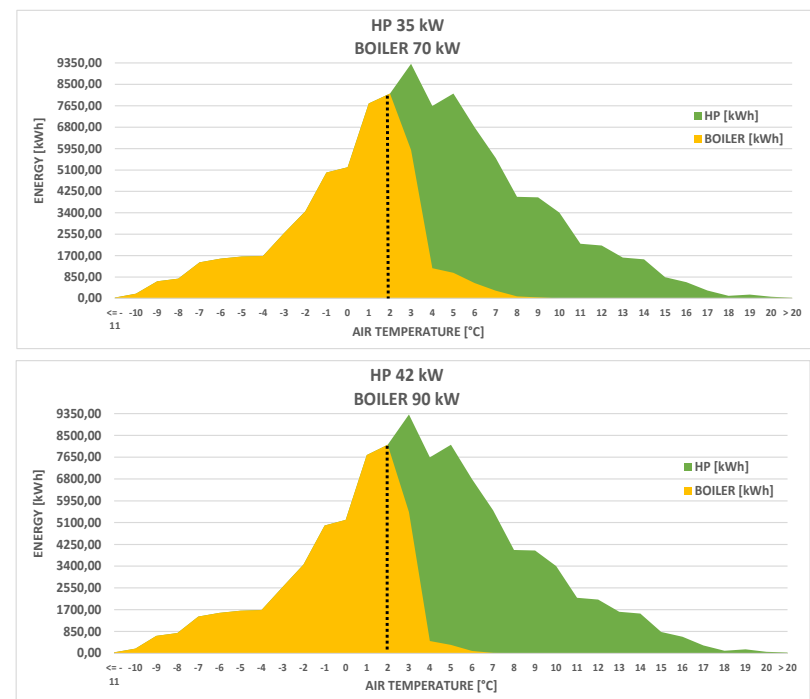

Fig. 5. Satisfaction of the energy needs for the three combinations - Milan, high temperature.

It is evident that, in the three considered configurations, the energy demand required at $\mathrm{T}_{\text {ext }}<+2{ }^{\circ} \mathrm{C}$ is completely satisfied by the boiler (fraction corresponding to $40.7 \%$ of the total). The result is that, considering the required delivery temperature and the operating limits, the heat pump has $\mathrm{T}_{\text {cut-off }}=+2{ }^{\circ} \mathrm{C}$, the temperature below which this generator does not work. Comparing the three system configurations, it is clear that, in the case of configuration with the $20 \mathrm{~kW}$ heat pump, the latter contributes $25.4 \%$ both in terms of primary energy use and $\mathrm{CO}_{2}$ emissions. In the case of a $35 \mathrm{~kW}$ heat pump, the percentage rises to $36.1 \%$ and $38.6 \%$ with a $42 \mathrm{~kW}$ heat pump. The reduction in the use of primary energy, between the first and the last configuration of the hybrid system, stands at $6,130.7$ $\mathrm{kWh}$, equivalent to a decrease of $7.13 \%$. Regarding $\mathrm{CO}_{2}$ emissions, the reduction is equal to $1,229.7 \mathrm{~kg}_{\mathrm{CO} 2}$, equivalent to a decrease of $7.16 \%$.

\section{Milan (Climatic Zone E) - Low Temperature Terminals}

Low temperature application is the best condition to propose an hybrid system. The hypothesis is to provide the terminals with the $\mathrm{T}_{\text {design }}$ temperature equal to $40{ }^{\circ} \mathrm{C}$ and a $\mathrm{T}_{\min }$ equal to $25^{\circ} \mathrm{C}$.

Fig. 6. Operating limits, in heating, of the heat pump and low temperature climatic curve.

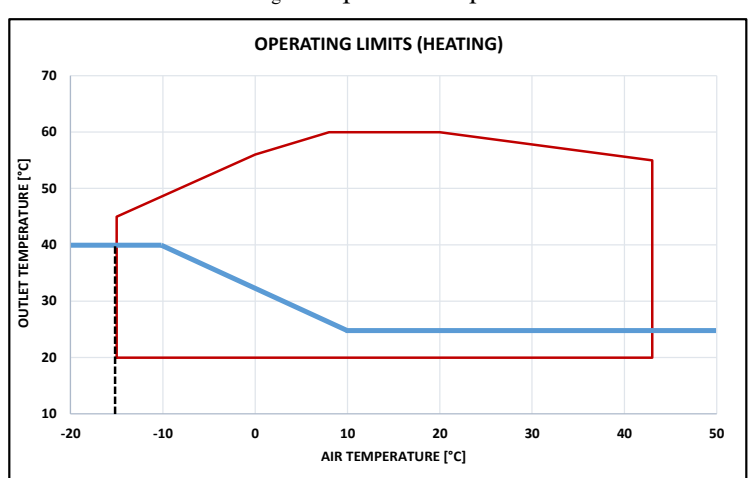


In this condition, the heat pump is always able to supply power to the system as the operating range is able to cover the temperatures required in any external condition. In this analysis the efficiency of the heat pump is always higher than the efficiency of the boiler, therefore a generator is not turned off for reasons of energy convenience. The boiler therefore always integrates the heat pump to complete the load requirement.

Table 10. Environmental aspects, low temperature plant - Milan.

\begin{tabular}{|c|c|c|c|c|c|}
\hline \multirow[b]{2}{*}{ Parameters } & \multirow[b]{2}{*}{ Generator } & \multirow[b]{2}{*}{ Unit } & \multicolumn{3}{|c|}{ GENERATORS } \\
\hline & & & $\begin{array}{c}\text { HP } 20 \mathrm{~kW} \\
\text { BOILER } 70 \mathrm{~kW}\end{array}$ & $\begin{array}{c}\text { HP } 35 \mathrm{~kW} \\
\text { BOILER } 70 \mathrm{~kW}\end{array}$ & $\begin{array}{c}\text { HP } 42 \mathrm{~kW} \\
\text { BOILER } 90 \mathrm{~kW}\end{array}$ \\
\hline \multirow{3}{*}{ Primary energy } & HP & \multirow{3}{*}{$\mathrm{kWh}$} & 38213,26 & 54614,52 & 58982,01 \\
\hline & BOILER & & 37399,10 & 13405,05 & 7194,11 \\
\hline & TOTAL & & 75612,36 & 68019,58 & 66176,12 \\
\hline \multirow{3}{*}{$\mathrm{CO}_{2}$ emissions } & HP & \multirow{3}{*}{$\mathrm{kg}_{\mathrm{CO} 2}$} & 7614,53 & 10882,71 & 11752,99 \\
\hline & BOILER & & 7472,34 & 2678,33 & 1437,38 \\
\hline & TOTAL & & 15086,87 & 13561,04 & 13190,38 \\
\hline
\end{tabular}

Table 11. Operational aspects, low temperature plant - Milan.

\begin{tabular}{|l|c|r|r|r|}
\hline \multirow{2}{*}{\multicolumn{1}{|c|}{ Parameters }} & \multirow{2}{*}{ Unit } & \multicolumn{3}{|c|}{ GENERATORS } \\
\cline { 3 - 5 } & & $\begin{array}{c}\text { HP } 20 \mathrm{~kW} \\
\text { BOILER 70 kW }\end{array}$ & $\begin{array}{c}\text { HP 35 kW } \\
\text { BOILER 70 kW }\end{array}$ & $\begin{array}{c}\text { HP 42 kW } \\
\text { BOILER 90 kW }\end{array}$ \\
\hline Energy demand & $\mathrm{kWh}$ & \multicolumn{3}{|c|}{97750,84} \\
\hline \multirow{2}{*}{ Energy provided - HP } & $\mathrm{kWh}$ & 59961,94 & 84216,01 & 90491,24 \\
\cline { 2 - 5 } & \multicolumn{1}{|c|}{$\%$} & $61,34 \%$ & $86,15 \%$ & $92,57 \%$ \\
\hline \multirow{2}{*}{ Energy provided - Boiler } & $\mathrm{kWh}$ & 37788,89 & 13534,82 & 7259,59 \\
\cline { 2 - 5 } & $\%$ & $38,66 \%$ & $13,85 \%$ & $7,43 \%$ \\
\hline \multirow{2}{*}{ Electricity absorbed - HP } & $\mathrm{kWh}$ & 17577,40 & 25121,68 & 27130,64 \\
\cline { 2 - 5 } & $€$ & 3515,48 & 5024,34 & 5426,13 \\
\hline \multirow{3}{*}{ Natural gas - Boiler } & $\mathrm{Sm}$ & 3490,15 & 1250,98 & 671,37 \\
\cline { 2 - 5 } & $\mathrm{kWh}$ & 37399,10 & 13405,05 & 7194,11 \\
\cline { 2 - 5 } & $€$ & 2792,12 & 1000,79 & 537,09 \\
\hline Usage cost & $€$ & 6307,60 & 6025,12 & 5963,22 \\
\hline
\end{tabular}

It is interesting to see that this type of plant allows to satisfy most of the thermal load using the heat pump even in the smaller size configuration of this generator $(20 \mathrm{~kW})$.

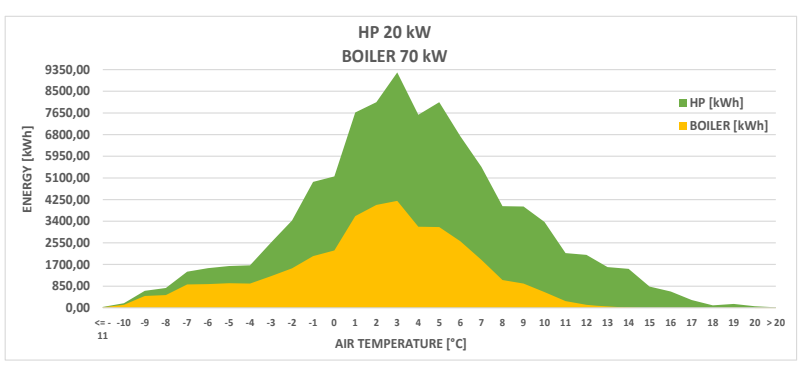




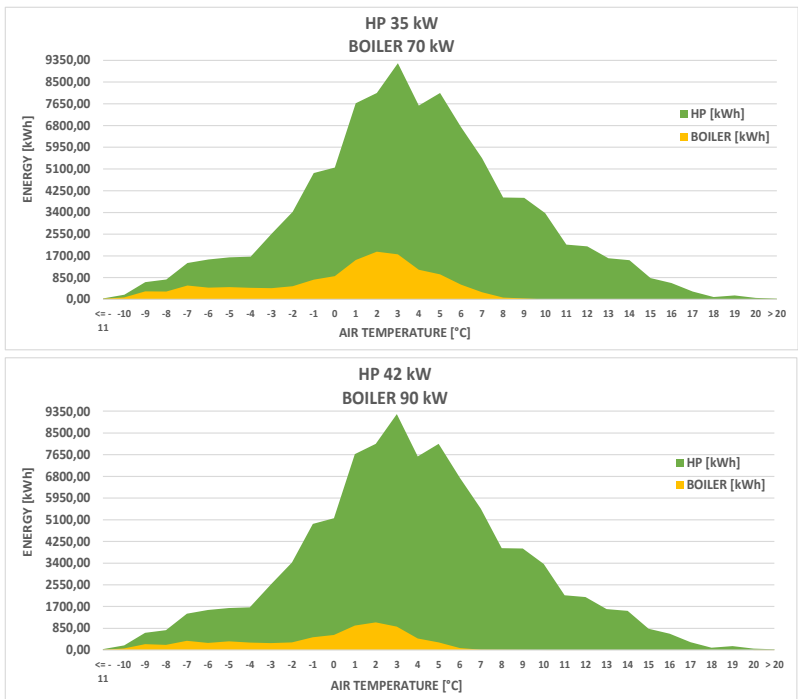

Fig. 7. Satisfaction of the energy needs for the three combinations - Milan, low temperature.

It is clear that the heat pump covers most of the energy needs of the building and the boiler only integrates peak demands. As already previously introduced, this is possible due to the fact that the temperature regulation with a climatic curve allows to work within the operating limits of the heat pump even at low external air temperatures, since the maximum delivery temperature required from the plant is equal to $40{ }^{\circ} \mathrm{C}$. Furthermore, this type of regulation, in the case of a low temperature system, ensures that there is not a cut-off temperature of the heat pump but, on the contrary, this generator is able to work in the whole outdoor air temperature range.

The energy demand of the building covered by the $20 \mathrm{~kW}$ heat pump is equal to $61.3 \%$, while in the configuration of the system with the $35 \mathrm{~kW}$ heat pump, the fraction satisfied increases to $86.1 \%$, up to $92.6 \%$ considering the larger size of this generator, $42 \mathrm{~kW}$.

Comparing the three combinations of the system, it is clear that, in the case of a $20 \mathrm{~kW}$ heat pump, this generator contributes $50.5 \%$ both to the use of primary energy and to $\mathrm{CO}_{2}$ emissions. In the case of a $35 \mathrm{~kW}$ heat pump, the percentage rises to $80.3 \%$, up to $89.1 \%$ in the case of a $42 \mathrm{~kW}$ heat pump. The reduction of primary energy used, between the first and last configuration of the hybrid system, stands at $9,436 \mathrm{kWh}$, equivalent to a decrease of $12.48 \%$. Regarding $\mathrm{CO}_{2}$ emissions, the reduction is equal to $1,896.5 \mathrm{~kg}_{\mathrm{CO} 2}$, equivalent to $12.57 \%$. 
3. Rome (Climatic Zone D) - High Temperature Terminals

Table 12. Environmental aspects, high temperature plant - Rome.

\begin{tabular}{|c|c|c|c|c|c|}
\hline \multirow[b]{2}{*}{ Parameters } & \multirow[b]{2}{*}{ Generator } & \multirow[b]{2}{*}{ Unit } & \multicolumn{3}{|c|}{ GENERATORS } \\
\hline & & & $\begin{array}{c}\text { HP } 20 \mathrm{~kW} \\
\text { BOILER } 60 \mathrm{~kW}\end{array}$ & $\begin{array}{c}\text { HP } 25 \mathrm{~kW} \\
\text { BOILER } 60 \mathrm{~kW}\end{array}$ & $\begin{array}{c}\text { HP } 35 \mathrm{~kW} \\
\text { BOILER } 70 \mathrm{~kW}\end{array}$ \\
\hline \multirow{3}{*}{ Primary energy } & HP & \multirow{3}{*}{$\mathrm{kWh}$} & 18368,01 & 19460,11 & 20178,10 \\
\hline & BOILER & & 11927,08 & 9933,57 & 8609,82 \\
\hline & TOTAL & & 30295,09 & 29393,67 & 28787,92 \\
\hline \multirow{3}{*}{$\mathrm{CO}_{2}$ emissions } & HP & \multirow{3}{*}{$\mathrm{kg}_{\mathrm{CO} 2}$} & 3660,08 & 3877,70 & 4020,77 \\
\hline & BOILER & & 2383,03 & 1984,73 & 1720,24 \\
\hline & TOTAL & & 6043,11 & 5862,43 & 5741,01 \\
\hline
\end{tabular}

Table 13. Operational aspects, high temperature plant - Rome.

\begin{tabular}{|c|c|c|c|c|}
\hline \multirow[b]{2}{*}{ Parameters } & \multirow[b]{2}{*}{ Unit } & \multicolumn{3}{|c|}{ GENERATORS } \\
\hline & & $\begin{array}{c}\text { HP } 20 \mathrm{~kW} \\
\text { BOILER } 60 \mathrm{~kW}\end{array}$ & $\begin{array}{c}\text { HP } 25 \mathrm{~kW} \\
\text { BOILER } 60 \mathrm{~kW}\end{array}$ & $\begin{array}{c}\text { HP } 35 \mathrm{~kW} \\
\text { BOILER } 70 \mathrm{~kW}\end{array}$ \\
\hline Energy demand & $\mathrm{kWh}$ & \multicolumn{3}{|c|}{45114,23} \\
\hline \multirow{2}{*}{ Energy provided - HP } & $\mathrm{kWh}$ & 33686,43 & 35652,30 & 36951,40 \\
\hline & $\%$ & $74,67 \%$ & $79,03 \%$ & $81,91 \%$ \\
\hline \multirow{2}{*}{ Energy provided - Boiler } & $\mathrm{kWh}$ & 11427,80 & 9461,92 & 8162,82 \\
\hline & $\%$ & $25,33 \%$ & $20,97 \%$ & $18,09 \%$ \\
\hline \multirow{2}{*}{ Electricity absorbed - HP } & $\mathrm{kWh}$ & 8448,95 & 8951,29 & 9281,55 \\
\hline & $€$ & 1689,79 & 1790,26 & 1856,31 \\
\hline \multirow{3}{*}{ Natural gas - Boiler } & $\mathrm{Sm}^{3}$ & 1113,06 & 927,02 & 803,48 \\
\hline & $\mathrm{kWh}$ & 11927,08 & 9933,57 & 8609,82 \\
\hline & $€$ & 890,45 & 741,62 & 642,79 \\
\hline Usage cost & $€$ & 2580,24 & 2531,87 & 2499,10 \\
\hline
\end{tabular}

The energy need covered by the $20 \mathrm{~kW}$ heat pump is $74.7 \%$, while in the configuration of the system with a $25 \mathrm{~kW}$ heat pump the fraction satisfied increases to $79.0 \%$, up to $81.9 \%$ considering the larger size of this generator, $35 \mathrm{~kW}$.

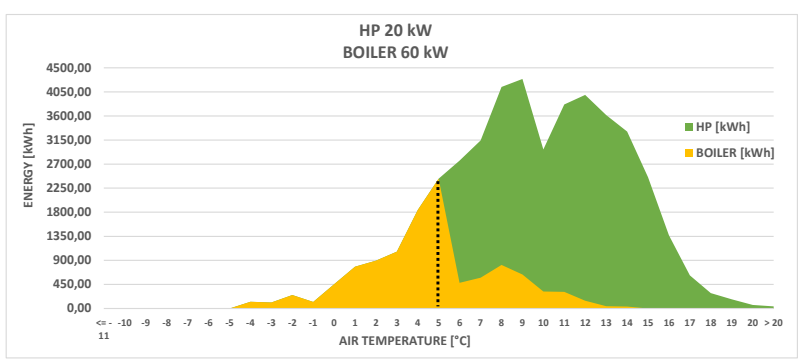




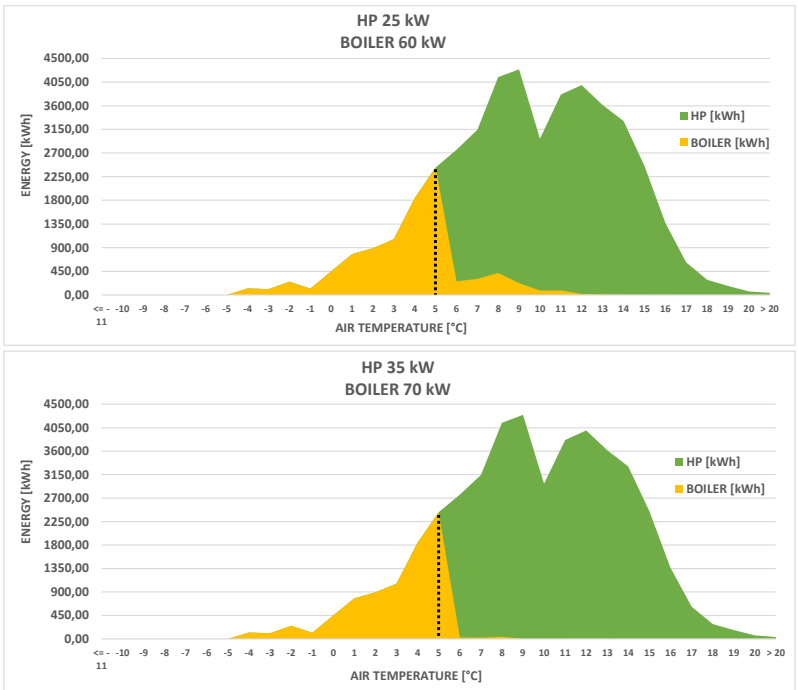

Fig. 8. Satisfaction of the energy needs for the three combinations - Rome, high temperature.

It is evident from the graphs that the energy demand required at $\mathrm{T}_{\text {ext }}<+5{ }^{\circ} \mathrm{C}$ is completely satisfied by the boiler (fraction corresponding to $17.9 \%$ of the total). It follows that, considering the required delivery temperature and the operating limits, the heat pump has $\mathrm{T}_{\text {cut-off }}=+5^{\circ} \mathrm{C}$ and this means that below this temperature the generator does not work.

Moving on to describe the data in Tab. 12, we can see that, in the case of configuration with the $20 \mathrm{~kW}$ heat pump, this generator contributes $60.6 \%$ both as regards the use of primary energy and emissions of $\mathrm{CO}_{2}$. In the case of a $25 \mathrm{~kW}$ heat pump, the percentage rises to $66.2 \%$ and $70.1 \%$ with a $35 \mathrm{~kW}$ heat pump. The reduction of primary energy used, between the first and last configuration of the hybrid system, stands at $1,507.2 \mathrm{kWh}$, equivalent to a decrease of $4.98 \%$. As regards $\mathrm{CO}_{2}$ emissions, the reduction is equal to $302.1 \mathrm{~kg}_{\mathrm{CO} 2}$, equivalent to a decrease of $5.00 \%$.

4. Roma (Climatic Zone D) - Low Temperature Terminals

Table 14. Environmental aspects, low temperature plant - Rome.

\begin{tabular}{|c|c|c|c|c|c|}
\hline \multirow[b]{2}{*}{ Parameters } & \multirow[b]{2}{*}{ Generator } & \multirow[b]{2}{*}{ Unit } & \multicolumn{3}{|c|}{ GENERATORS } \\
\hline & & & $\begin{array}{c}\text { HP } 20 \mathrm{~kW} \\
\text { BOILER } 60 \mathrm{~kW}\end{array}$ & $\begin{array}{c}\text { HP } 25 \mathrm{~kW} \\
\text { BOILER } 60 \mathrm{~kW}\end{array}$ & $\begin{array}{c}\text { HP } 35 \mathrm{~kW} \\
\text { BOILER } 70 \mathrm{~kW}\end{array}$ \\
\hline \multirow{3}{*}{ Primary energy } & HP & \multirow{3}{*}{ kWh } & 22038,05 & 23532,84 & 24702,98 \\
\hline & BOILER & & 4753,56 & 2285,26 & 428,34 \\
\hline & TOTAL & & 26791,61 & 25818,10 & 25131,33 \\
\hline \multirow{3}{*}{$\mathrm{CO}_{2}$ emissions } & HP & \multirow{3}{*}{$\mathrm{kg}_{\mathrm{CO} 2}$} & 4391,39 & 4689,25 & 4922,42 \\
\hline & BOILER & & 949,76 & 456,59 & 85,58 \\
\hline & TOTAL & & 5341,15 & 5145,84 & 5008,00 \\
\hline
\end{tabular}


Table 15. Operational aspects, low temperature plant - Rome.

\begin{tabular}{|c|c|c|c|c|}
\hline \multirow[b]{2}{*}{ Parameters } & \multirow[b]{2}{*}{ Unit } & \multicolumn{3}{|c|}{ GENERATORS } \\
\hline & & $\begin{array}{c}\text { HP } 20 \mathrm{~kW} \\
\text { BOILER } 60 \mathrm{~kW}\end{array}$ & $\begin{array}{c}\text { HP } 25 \mathrm{~kW} \\
\text { BOILER } 60 \mathrm{~kW}\end{array}$ & $\begin{array}{c}\text { HP } 35 \mathrm{~kW} \\
\text { BOILER } 70 \mathrm{~kW}\end{array}$ \\
\hline Energy demand & $\mathrm{kWh}$ & \multicolumn{3}{|c|}{44406,64} \\
\hline \multirow{2}{*}{ Energy provided - HP } & $\mathrm{kWh}$ & 39599,13 & 42096,91 & 43974,64 \\
\hline & $\%$ & $89,17 \%$ & $94,80 \%$ & $99,03 \%$ \\
\hline \multirow{2}{*}{ Energy provided - Boiler } & $\mathrm{kWh}$ & 4807,51 & 2309,73 & 432,00 \\
\hline & $\%$ & $10,83 \%$ & $5,20 \%$ & $0,97 \%$ \\
\hline \multirow{2}{*}{ Electricity absorbed - HP } & $\mathrm{kWh}$ & 10137,10 & 10824,67 & 11362,92 \\
\hline & $€$ & 2027,42 & 2164,93 & 2272,58 \\
\hline \multirow{3}{*}{ Natural gas - Boiler } & Sm3 & 443,61 & 213,26 & 39,97 \\
\hline & $\mathrm{kWh}$ & 4753,56 & 2285,26 & 428,34 \\
\hline & $€$ & 354,89 & 170,61 & 31,98 \\
\hline Usage cost & $€$ & 2382,31 & 2335,55 & 2304,56 \\
\hline
\end{tabular}

Describing the data in Tab. 14, it is clear that, in the case of configuration with the $20 \mathrm{~kW}$ heat pump, this generator contributes $82.3 \%$ both as regards the use of primary energy and $\mathrm{CO}_{2}$ emissions. In the case of a $25 \mathrm{~kW}$ heat pump, the percentage rises to $91.1 \%$, up to $98.3 \%$ with a $35 \mathrm{~kW}$ heat pump. The reduction of primary energy used, between the first and last configuration of the hybrid system, stands at $1,660.3 \mathrm{kWh}$, equivalent to a decrease of $6.19 \%$. As regards $\mathrm{CO}_{2}$ emissions, the reduction is equal to $333.2 \mathrm{~kg}_{\mathrm{CO} 2}$, equivalent to $6.24 \%$.

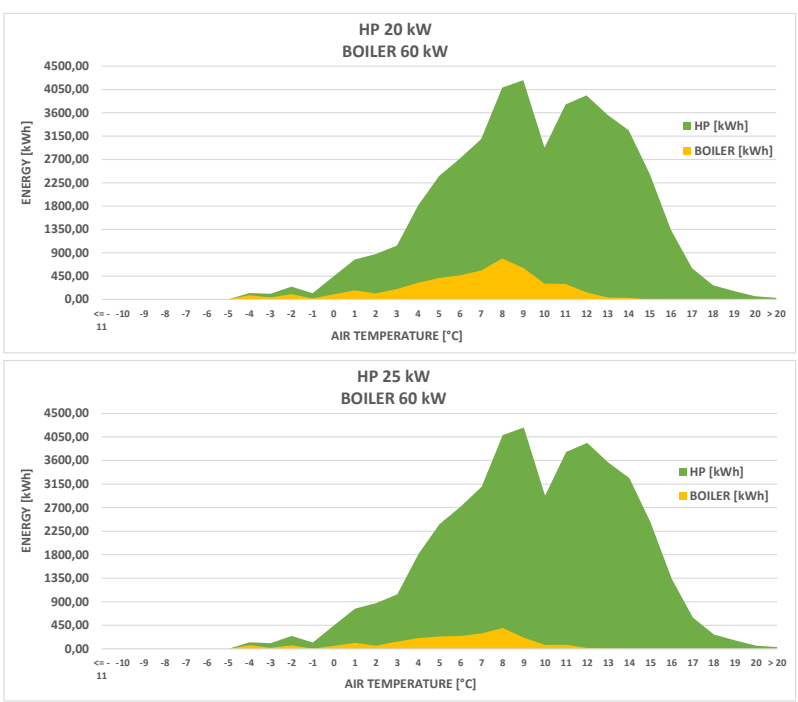




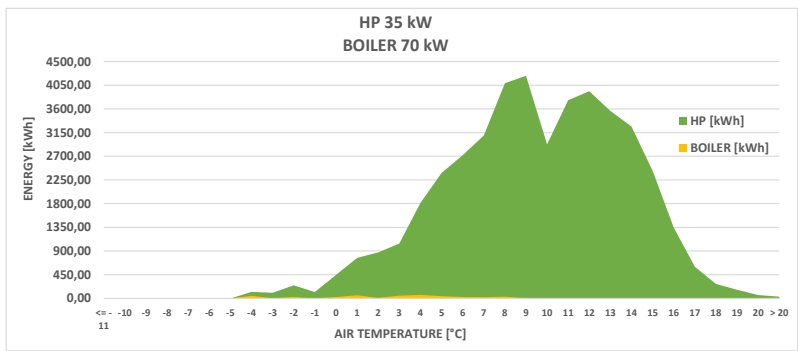

Fig. 9. Satisfaction of the energy needs for the three combinations - Rome, low temperature.

The milder climatic conditions than the case of Milan, combined with lower peak demands, mean that the $20 \mathrm{~kW}$ heat pump is able to satisfy $89.2 \%$, while in the system configuration with a $25 \mathrm{~kW}$ heat pump the satisfied fraction rises to $94.8 \%$, up to $99.0 \%$ considering the largest size of this generator, $35 \mathrm{~kW}$.

Also in this case, the regulation of the $T_{m}$ using a climatic curve in the case of a low temperature system, ensures that there is not a cut-off temperature of the heat pump but, on the contrary, the generator is able to work throughout all the outside air temperature range.

Here below are reported the most significant quantities deriving from the comparison with a standard efficiency boiler, whose efficiency has been assumed to be equal to 0.80 .

- High Temperature

Table 16. Comparison between hybrid system and standard efficiency boiler, Milan and Rome - high temperature.

\begin{tabular}{|c|c|c|c|c|c|c|c|c|c|}
\hline \multirow[b]{2}{*}{ Parameters } & \multirow[b]{2}{*}{ Unit } & \multicolumn{4}{|c|}{ MILAN - CLIMATIC ZONE E } & \multicolumn{4}{|c|}{ ROME - CLIMATIC ZONE D } \\
\hline & & $\begin{array}{c}\text { Standard } \\
\text { Boiler }\end{array}$ & $\begin{array}{l}\text { HP } 20 \mathrm{~kW} \\
\text { Boiler } 70 \mathrm{~kW}\end{array}$ & $\begin{array}{c}\text { HP } 35 \mathrm{~kW} \\
\text { Boiler } 70 \mathrm{~kW}\end{array}$ & $\begin{array}{c}\text { HP } 42 \mathrm{~kW} \\
\text { Boiler } 90 \mathrm{~kW}\end{array}$ & $\begin{array}{c}\text { Standard } \\
\text { Boiler }\end{array}$ & $\begin{array}{c}\text { HP } 20 \mathrm{~kW} \\
\text { Boiler } 60 \mathrm{~kW}\end{array}$ & $\begin{array}{c}\text { HP } 25 \mathrm{~kW} \\
\text { Boiler } 60 \mathrm{~kW}\end{array}$ & $\begin{array}{c}\text { HP } 35 \mathrm{~kW} \\
\text { Boiler } 70 \mathrm{~kW}\end{array}$ \\
\hline \multirow{2}{*}{ Primary energy } & kWh & 130491,8 & 85984,0 & 80946,0 & 79853,3 & 59691,2 & 30295,1 & 29393,7 & 28787,9 \\
\hline & $\%$ & - & $-34,1 \%$ & $-38,0 \%$ & $-38,8 \%$ & - & $-49,3 \%$ & $-50,8 \%$ & $-51,8 \%$ \\
\hline \multirow{2}{*}{$\mathrm{CO}_{2}$ emissions } & $\mathrm{kg}_{\mathrm{CO} 2}$ & 26072,3 & 17167,9 & 16157,4 & 15938,2 & 11926,3 & 6043,1 & 5862,4 & 5741,0 \\
\hline & $\%$ & - & $-34,2 \%$ & $-38,0 \%$ & $-38,9 \%$ & - & $-49,3 \%$ & $-50,8 \%$ & $-51,9 \%$ \\
\hline \multirow{2}{*}{ Annual usage cost } & $€$ & 9742,20 & 6798,40 & 6549,40 & 6496,70 & 4456,40 & 2580,20 & 2531,90 & 2499,1 \\
\hline & $\%$ & . & $-30,2 \%$ & $-32,8 \%$ & $-33,3 \%$ & & $-42,1 \%$ & $-43,2 \%$ & $-43,9 \%$ \\
\hline
\end{tabular}

- Low Temperature

Table 17. Comparison between hybrid system and standard efficiency boiler, Milan and Rome - low temperature.

\begin{tabular}{|c|c|c|c|c|c|c|c|c|c|}
\hline \multirow[b]{2}{*}{ Parameters } & \multirow[b]{2}{*}{ Unit } & \multicolumn{4}{|c|}{ MILAN - CLIMATIC ZONE E } & \multicolumn{4}{|c|}{ ROME - CLIMATIC ZONE D } \\
\hline & & $\begin{array}{c}\text { Standard } \\
\text { Boiler }\end{array}$ & $\begin{array}{l}\text { HP } 20 \mathrm{~kW} \\
\text { Boiler } 70 \mathrm{~kW}\end{array}$ & $\begin{array}{l}\text { HP } 35 \mathrm{~kW} \\
\text { Boiler } 70 \mathrm{~kW}\end{array}$ & $\begin{array}{l}\text { HP } 42 \mathrm{~kW} \\
\text { Boiler } 90 \mathrm{~kW}\end{array}$ & $\begin{array}{l}\text { Standard } \\
\text { Boiler }\end{array}$ & $\begin{array}{l}\text { HP } 20 \mathrm{~kW} \\
\text { Boiler } 60 \mathrm{~kW}\end{array}$ & $\begin{array}{l}\text { HP } 25 \mathrm{~kW} \\
\text { Boiler } 60 \mathrm{~kW}\end{array}$ & $\begin{array}{c}\text { HP } 35 \mathrm{~kW} \\
\text { Boiler } 70 \mathrm{~kW}\end{array}$ \\
\hline \multirow{2}{*}{ Primary energy } & kWh & 129335,3 & 75612,4 & 68019,6 & 66176,1 & 58754,9 & 26791,6 & 25818,1 & 25131,3 \\
\hline & $\%$ & - & $-41,5 \%$ & $-47,4 \%$ & $-48,8 \%$ & - & $-54,4 \%$ & $-56,1 \%$ & $-57,2 \%$ \\
\hline \multirow{2}{*}{$\mathrm{CO}_{2}$ emissions } & $\mathrm{kg}_{\mathrm{cO2} 2}$ & 25841,2 & 15086,9 & 13561,0 & 13190,4 & 11739,2 & 5341,2 & 5145,8 & 5008,0 \\
\hline & $\%$ & - & $-41,6 \%$ & $-47,5 \%$ & $-49,0 \%$ & - & $-54,5 \%$ & $-56,2 \%$ & $-57,3 \%$ \\
\hline \multirow{2}{*}{ Annual usage cost } & $€$ & 9655,90 & 6307,60 & 6025,10 & 5963,20 & 4386,50 & 2382,30 & 2335,60 & 2304,60 \\
\hline & $\%$ & - & $-34,7 \%$ & $-37,6 \%$ & $-38,2 \%$ & & $-45,7 \%$ & $-46,8 \%$ & $-47,5 \%$ \\
\hline
\end{tabular}


In the case of Milan, depending on the size of the hybrid generator, the reduction in primary energy used is between $34.1 \%$ (corresponding to $44,508 \mathrm{kWh}$ ) and $38.8 \%(50,639 \mathrm{kWh}$ ) in high temperature plant, up to values between $41.5 \%(53,723 \mathrm{kWh})$ and $48.8 \%(63,159 \mathrm{kWh})$ in low temperature plant. Another important aspect regarding the environmental sustainability is represented by the significant reduction in carbon dioxide $\left(\mathrm{CO}_{2}\right)$ emissions, with percentage values similar to the previous ones. In terms of absolute values, the decreases are between $8,904 \mathrm{~kg}$ and $10,134 \mathrm{~kg}$ in high temperature systems, up to values between $10,754 \mathrm{~kg}$ and $12,651 \mathrm{~kg}$ in low temperature applications.

In the case of Rome, depending on the size of the hybrid generator, the reduction in primary energy used is between $49.3 \%$ (corresponding to $29,396 \mathrm{kWh})$ and $51.8 \%(30,903 \mathrm{kWh})$ in high temperature systems, up to values between $54.4 \%(31,963 \mathrm{kWh})$ and $57.2 \%(33,624$ $\mathrm{kWh})$ in low temperature. There is also a significant reduction in carbon dioxide $\left(\mathrm{CO}_{2}\right)$ emissions, with percentage values similar to those of primary energy. In terms of absolute values, the decreases are between $5,883 \mathrm{~kg}$ and $6,185 \mathrm{~kg}$ in high temperature systems, up to values that are between $6,398 \mathrm{~kg}$ and $6,731 \mathrm{~kg}$ in low temperature applications.

As overall view, it is clear that a bigger heat pump allows to improve the $\mathrm{CO}_{2}$ emissions reduction and primary energy savings, even if the difference with the case of the smaller heat pump is not so relevant.

\section{Economic analysis of the investment}

The following assessments will simulate two different scenarios: access to the Superbonus $110 \%$ or access to the Ecobonus $65 \%$. This choice has been made because this study wants to find the best solution in the context of a renovation of a dated building that is, therefore, energy inefficient. It is precisely in this area that the Italian Government has allocated the aforementioned incentives, in order to facilitate the transition and energy optimization.

The analysis, which takes into account the real costs of the generators and storage tank, aims to evaluate the feasibility and convenience of the investment considering a time span of 10 years. For each considered case, a database has been created where the values of:

- Annual savings (compared to a system with a standard efficiency boiler only);

- Return on investment in the case of Ecobonus $65 \%$ and Superbonus $110 \%$;

- Return time of the initial investment (Payback period);

- Discounted cash flows;

- $\quad$ Net present value (NPV);

- Internal rate of return $(I R R)$;

- Daily cost (Ecobonus 65\% and 110\%).

The results obtained for each city, system combination and type of plant are shown in the following pages. 


\section{Milan (Climatic Zone E)}

Table 18. Economic indices - Milan, high and low temperature.

\begin{tabular}{|c|c|c|c|c|c|c|c|c|}
\hline & \multirow[b]{2}{*}{ Parameters } & \multirow[b]{2}{*}{ Unit } & \multicolumn{3}{|c|}{ HIGH TEMPERATURE } & \multicolumn{3}{|c|}{ LOW TEMPERATURE } \\
\hline & & & $\begin{array}{c}\text { HP } 20 \mathrm{~kW} \\
\text { Boiler } 70 \mathrm{~kW}\end{array}$ & $\begin{array}{c}\text { HP } 35 \mathrm{~kW} \\
\text { Boiler } 70 \mathrm{~kW}\end{array}$ & $\begin{array}{c}\text { HP } 42 \mathrm{~kW} \\
\text { Boiler } 90 \mathrm{~kW}\end{array}$ & $\begin{array}{c}\text { HP } 20 \mathrm{~kW} \\
\text { Boiler } 70 \mathrm{~kW}\end{array}$ & $\begin{array}{c}\text { HP } 35 \mathrm{~kW} \\
\text { Boiler } 70 \mathrm{~kW}\end{array}$ & $\begin{array}{c}\text { HP } 42 \mathrm{~kW} \\
\text { Boiler } 90 \mathrm{~kW}\end{array}$ \\
\hline \multicolumn{2}{|c|}{ Initial investment } & \multirow{2}{*}{$\epsilon$} & 26194,30 & 31223,50 & 35252,80 & 26194,30 & 31223,50 & 35252,80 \\
\hline \multicolumn{2}{|c|}{ Annual usage cost } & & 6798,40 & 6549,40 & 6496,70 & 6307,60 & 6025,10 & 5963,20 \\
\hline \multirow{4}{*}{ 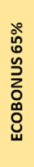 } & NPV & $€$ & 11985,61 & 11789,90 & 10473,61 & 15179,75 & 15248,30 & 14004,80 \\
\hline & IRR & $\%$ & 14,99 & 13,37 & 11,66 & 17,37 & 15,60 & 13,77 \\
\hline & Payback period & years & 4,13 & 4,31 & 4,50 & 3,88 & 4,06 & 4,26 \\
\hline & Daily cost & $€$ & 21,52 & 21,39 & 21,69 & 20,17 & 19,95 & 20,23 \\
\hline \multirow{4}{*}{ 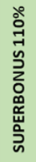 } & NPV & $€$ & 20026,11 & 21374,15 & 21294,68 & 23220,30 & 24832,55 & 24825,86 \\
\hline & IRR & $\%$ & 22,52 & 20,99 & 19,40 & 24,77 & 23,10 & 21,37 \\
\hline & Payback period & years & 3,20 & 3,31 & 3,42 & 3,05 & 3,16 & 3,28 \\
\hline & Daily cost & $€$ & 18,63 & 17,94 & 17,80 & 17,28 & 16,51 & 16,34 \\
\hline
\end{tabular}

The first difference between the different sizes of the hybrid system is the initial investment which, clearly, increases with the size of the heat pumps. In fact, there is a difference of $9,058.50 €$ (corresponding to $34.6 \%$ ) between the initial investment for the smallest configuration of the system and the largest.

- Ecobonus 65\% - High Temperature Terminals

The NPV value is almost the same for the two configurations of the hybrid system with 70 $\mathrm{kW}$ boiler (11,985.61 $€$ and 11,789.90 $€$ respectively), while for the option with $42 \mathrm{~kW}$ heat pump and $90 \mathrm{~kW}$ boiler, is recorded a slightly lower value $(10,473.61 €)$. This is equivalent to saying that, investing $9,058.50 €$ more in the initial instant, at the end of the tenth year there is a return of $1,500 €$ less than the initial minor investment. Looking at the IRR value, it can be seen that the most favorable is the one resulting from the investment for the smallest configuration of the hybrid generator $(15.0 \%)$. The worst, even in this case, is the one related to the higher initial investment $(11.7 \%)$. Starting from what has just been described and considering the other tabulated data, it follows that by taking advantage of the $65 \%$ incentive, the investment that is most convenient, from a purely economic point of view, is the one for the smallest size of the hybrid system (HP $20 \mathrm{~kW}$, boiler $70 \mathrm{~kW}$ ).

- Ecobonus 65\% - Low Temperature Terminals

The NPV value is almost the same for the two configurations of the hybrid system with 70 $\mathrm{kW}$ boiler (respectively $15,179.75 €$ and $15,248.30 €$ ), while for the option with $42 \mathrm{~kW}$ heat pump and $90 \mathrm{~kW}$ boiler, is recorded a slightly lower value $(14,004.79 €)$. This is equivalent to saying that, investing $9,058.50 €$ more in the initial instant, at the end of the tenth year there is a return of $1,200 €$ less than the initial minor investment, thus making this solution less convenient from an economic point of view. Looking now at the IRR value, it can be seen that the most favourable is the one resulting from the investment for the smallest configuration of the hybrid generator $(17.4 \%)$. The worst, even in this case, is the one related to the higher initial investment $(13.8 \%)$. Starting from what has just been described and considering the other tabulated data, it follows that by taking advantage of the $65 \%$ incentive, the investment that is most convenient, from a purely economic point of view, is the one for the smallest size of the hybrid system (HP $20 \mathrm{~kW}$, boiler $70 \mathrm{~kW}$ ). 
- Superbonus $110 \%$ - High Temperature Terminals

The value of the NPV is almost the same (about 21,300 $€$ ) for the configurations of the hybrid system with 35 and $42 \mathrm{~kW}$ heat pump, while for the option with $20 \mathrm{~kW}$ heat pump a lower value is recorded $(20,026.11 €)$. This is equivalent to saying that, saving $9,058.50 €$ in the initial instant, at the end of the tenth year there is, however, a return of 1,300 $€$ less than in the case with a higher initial investment. Looking now at the IRR value, it can be seen that the most favourable is the one deriving from the investment for the smallest configuration of the hybrid generator $(22.5 \%)$. The worst is the one related to the higher initial investment $(19.4 \%)$. Starting from what has just been described and considering the other tabulated data, it follows that by taking advantage of the $110 \%$ incentive, the most convenient solution, also taking into account the greater energy supply provided by the heat pump, is the medium size of the hybrid system (HP $35 \mathrm{~kW}, 70 \mathrm{~kW}$ boiler), followed closely by the minor investment which returns slightly lower NPV but higher IRR.

- Superbonus $110 \%$ - Low Temperature Terminals

The NPV value is almost the same $(24,832.55 €$ and $24,825.86 €)$ for the hybrid system configurations with $35 \mathrm{~kW}$ and $42 \mathrm{~kW}$ heat pump, while for the $20 \mathrm{~kW}$ heat pump option a slightly lower value is recorded $(23,220.26 €)$. This is equivalent to saying that, saving $9,058.50 €$ in the initial instant, at the end of the tenth year there is a return of only $1,600 €$ less than in the case with a higher initial investment. Looking now at the IRR value, it can be seen that the most favourable is the one resulting from the investment for the smallest configuration of the hybrid generator $(24.8 \%)$. The worst is the one related to the higher initial investment $(21.4 \%)$. Starting from what has just been described and considering the other tabulated data, it follows that by taking advantage of the $110 \%$ incentive there is not a single more convenient solution. In fact, the minor and medium-sized investments are equally valid but, also taking into account the energy supply provided by the heat pump, it is preferable to invest in the medium size of the hybrid system ( $35 \mathrm{~kW} \mathrm{HP,} 70 \mathrm{~kW}$ boiler).

In support of what has just been described, we now report the trend of discounted cash flows, also considering the initial investment:

Fig. 10. Trend in discounted cash flows - Milan, low temperature.

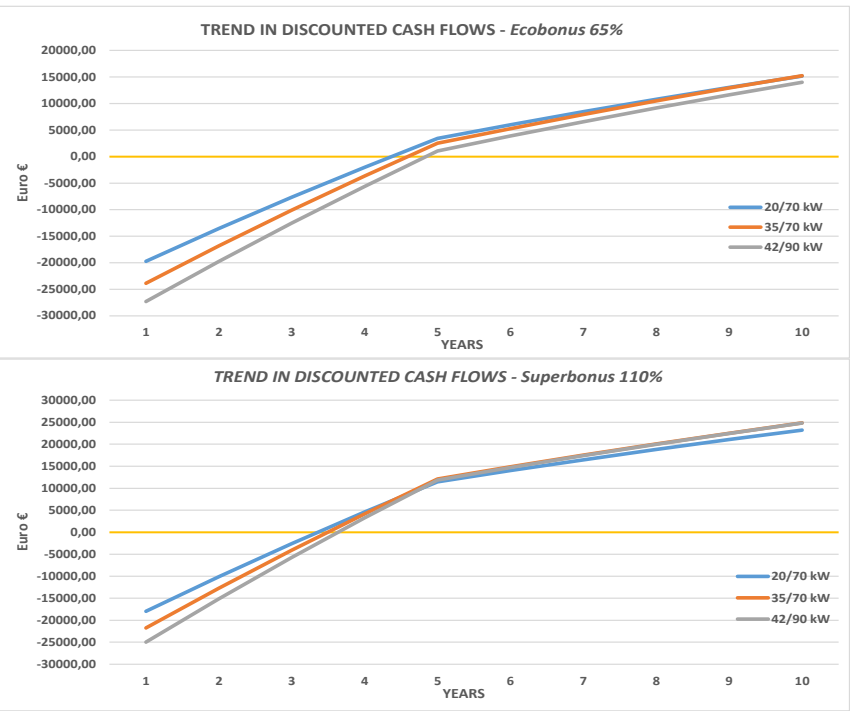


In the case of Ecobonus it is clear from the graph that the minor investment generates the same revenues as the medium solution, while in the case of Superbonus we can see that the more convenient investment is the medium one that generates the same revenues as the higher investment.

\section{Rome (Climatic Zone D)}

Table 19. Economic indices - Rome, high and low temperature.

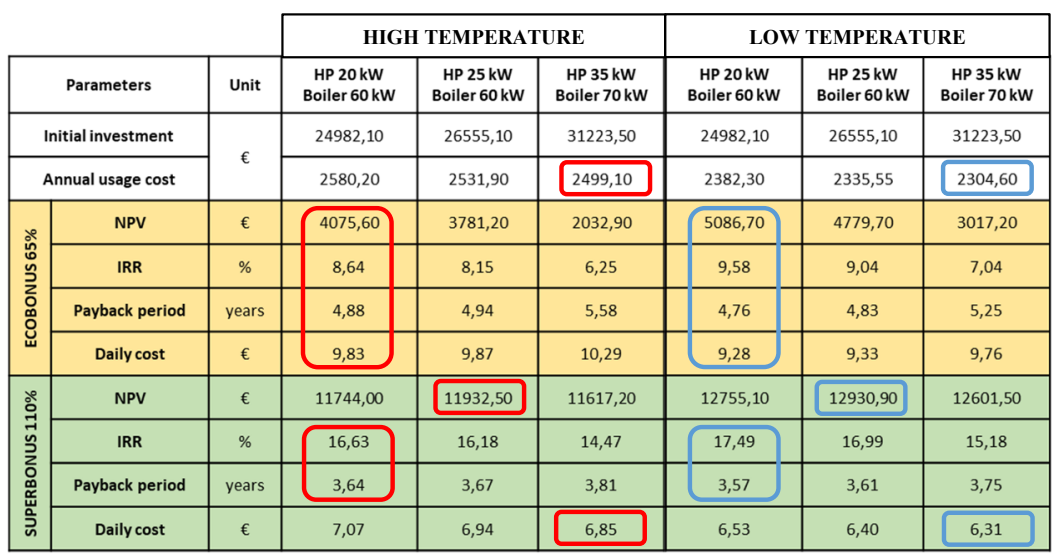

The first difference between the different sizes of the hybrid system is the initial investment. In fact, there is a difference of $6,241.40 €$ (corresponding to $25.0 \%$ ) between the initial investment for the smallest configuration of the system and the largest.

\section{- Ecobonus 65\% - High Temperature Terminals}

The NPV value is almost similar for the two configurations of the hybrid system with $60 \mathrm{~kW}$ boiler (respectively 4,075.59€ and 3,781.22 $€$ ), while a lower value is recorded for the option with $35 \mathrm{~kW}$ heat pump and $70 \mathrm{~kW}$ boiler $(2,032.92 €)$. This is equivalent to saying that, by investing 6,241.40 $€$ more in the initial instant, at the end of the tenth year there is a return of $2,100 €$ less than the initial minor investment. Looking now at the IRR value, it can be seen that the most favourable is the one resulting from the investment for the smallest configuration of the hybrid generator $(8.6 \%)$. The worst, even in this case, is the one related to the higher initial investment $(6.3 \%)$. Starting from what has just been described and considering the other tabulated data, it follows that by taking advantage of the $65 \%$ incentive, the investment that is most convenient, from a purely economic point of view, is the one for the smallest size of the hybrid system (HP $20 \mathrm{~kW}$, boiler $60 \mathrm{~kW})$.

- Ecobonus 65\% - Low Temperature Terminals

The value of the NPV is almost the same for the two configurations of the hybrid system with a $60 \mathrm{~kW}$ boiler (5,086.67 $€$ and 4,779.67 $€$ respectively), while a lower value is recorded for the option with a $35 \mathrm{~kW}$ heat pump and a $70 \mathrm{~kW}$ boiler, equal to $3,017.23 €$. This is equivalent to saying that, by investing $6,241.40 €$ more in the initial instant, at the end of the tenth year there is a return of $2,000 €$ less than the initial minor investment. Looking now at the IRR value, it can be seen that the most favourable is the one resulting from the investment for the smallest configuration of the hybrid generator $(9.6 \%)$. The worst, however, is the one related 
to the higher initial investment (7.0\%). Starting from what has just been described and considering the other tabulated data, it follows that by taking advantage of the $65 \%$ incentive, the investment that is most convenient, from a purely economic point of view, is the one for the smallest size of the hybrid system (HP $20 \mathrm{~kW}$, boiler $60 \mathrm{~kW}$ ).

- Superbonus $110 \%$ - High Temperature Terminals

The value of the NPV is almost the same for all configurations of the hybrid system: respectively $11,744.00 €, 11,932.47 €$ and $11,617.16 €$ in increasing order in terms of installed power. This is equivalent to say that, taking into account the modest energy quantities involved, the various investments generate equivalent economic results, thus preferring a more contained investment. Looking now at the IRR value, it can be seen that the most favorable is the one resulting from the investment for the smallest configuration of the hybrid generator $(16.6 \%)$. The worst is the one related to the higher initial investment $(14.5 \%)$. Starting from what has just been described and considering the other tabulated data, it follows that by taking advantage of the $110 \%$ incentive, the most convenient solution, also considering the greater energy supply provided by the heat pump, is the intermediate size of the hybrid system (HP $25 \mathrm{~kW}, 60 \mathrm{~kW}$ boiler), followed closely by the minor investment which returns slightly lower NPV, but higher IRR.

- Superbonus $110 \%$ - Low Temperature Terminals

The value of the NPV is almost the same for all configurations of the hybrid system: respectively $12,755.08 €, 12,930.92 €$ and $12,601.47 €$ in increasing order in terms of installed power. This is equivalent to saying that, taking into account the modest energy quantities involved, the various investments generate equivalent economic results thus preferring a more contained investment. Looking now at the IRR value, it can be seen that the most favourable is the one resulting from the investment for the smallest configuration of the hybrid generator $(17.5 \%)$. The worst, even in this case, is the one related to the higher initial investment (15.2\%). Starting from what has just been described and considering the other tabulated data, it follows that by taking advantage of the $110 \%$ incentive there is no single more convenient solution. In fact, the minor and medium-sized investments are equally valid but, also taking into account the energy supply provided by the heat pump, it is preferable to invest in the intermediate size of the hybrid system (HP $25 \mathrm{~kW}$, boiler $60 \mathrm{~kW}$ ).

\section{Conclusions}

The most significant results achieved (energy and economic) are shown now. The following reductions have been calculated as the average between the values deriving from the different sizes of the system:

- High Temperature Systems $\left(T_{\max }=70^{\circ} \mathrm{C}\right)$

This type of system is the most problematic because it allows a more limited use of the heat pump, which is able to produce a maximum water temperature of $60^{\circ} \mathrm{C}$.

1. Milan: it is achieved an average decrease in operating costs of $31.5 \%(3,150 €)$. As regards primary energy, there is an average saving of $36.5 \%(47,500 \mathrm{kWh})$. Finally, $\mathrm{CO}_{2}$ emissions also drop by $36.5 \%\left(9,500 \mathrm{~kg}_{\mathrm{CO} 2}\right)$.

2. Rome: it is achieved an average decrease in operating costs of $43.0 \%(1,950 €)$. As regards primary energy, there is an average saving of $50.5 \%(30,200 \mathrm{kWh})$. Finally, $\mathrm{CO}_{2}$ emissions also drop by $50.5 \%\left(6,050 \mathrm{~kg}_{\mathrm{CO} 2}\right)$. 
- Low Temperature Systems $\left(T_{\max }=40^{\circ} \mathrm{C}\right)$

This type of system is the most favourable since it allows the greater and more efficient use of the heat pump.

1. Milan: it is achieved an average decrease in operating costs of $36.5 \%(3,500 €)$. As regards primary energy, there is an average saving of $45.5 \%(58,500 \mathrm{kWh})$. Finally, $\mathrm{CO}_{2}$ emissions also drop by $45.5 \%\left(11,800 \mathrm{~kg}_{\mathrm{CO} 2}\right)$.

2. Rome: it is achieved an average decrease in operating costs of $46.5 \%(2,000 €)$. As regards primary energy, there is an average saving of $55.5 \%(32,750 \mathrm{kWh})$. Finally, $\mathrm{CO}_{2}$ emissions also drop by $55.5 \%\left(6,580 \mathrm{~kg}_{\mathrm{CO} 2}\right)$.

Summarizing, for each type of plants, the greatest percentage reductions occur in climatic zones with a warmer climate (Rome), even if in terms of absolute values the greatest reductions occur in Milan: the reason is found in the climate conditions that significantly increase the energy need of the building. Furthermore, as already mentioned, the greatest decreases are reached in the case of a low temperature system, as the temperature required by the system $\left(40{ }^{\circ} \mathrm{C}\right)$ ensures that the heat pump is able to work for every external air temperature value and, being the most efficient and least pollutant generator, it allows to achieve even more significant improvements.

From the economic analysis it emerges that, regardless of the size of the hybrid generator, with the Superbonus $110 \%$ incentive, the payback period $(P B)$ results, for both climatic zones and types of systems:

$$
3 \text { years }<P B<3.8 \text { years }
$$

While, in the case of the Ecobonus $65 \%$ incentive, there are different payback times based on the climatic zone, but similar for the different types of systems:

$$
\begin{array}{ll}
\text { Milan: } & 3.9 \text { years }<P B<4.5 \text { years } \\
\text { Rome: } & 4.8 \text { years }<P B<5.6 \text { years }
\end{array}
$$

Furthermore, also considering the NPV and IRR values as well as the PB, for all climatic zones, the results show that by taking advantage of the $65 \%$ incentive, end users are pushed to invest in the smaller size of the hybrid system, as it generates more advantageous economic quantities. On the contrary, with the $110 \%$ incentive, end users are pushed to support a greater investment, in particular for the medium size of the generator. Comparing the NPV and the IRR values between the different climatic zones, therefore evaluate where the investment for the hybrid system is more convenient, it can be said that the best economic results are obtained where the external air conditions are more rigid (Milan). The reason is that, as there are greater energy needs, the generator brings greater savings and revenues. Consequently where the climatic conditions are milder (Rome), therefore where the energy needs are limited, the economic indices assume lower values.

This analysis demonstrates how the energy efficiency of an existing multi-dwelling building can be implemented by renewing the thermal power plant with a Factory Made hybrid system in both high-temperature and low-temperature applications. Clearly the system terminals, and the envelope itself, greatly influence the behavior of a hybrid system of this type, both for the temperatures involved and the peak demand of the building. The results show that the best compromise between initial investment and primary energy reduction is the one with the lower ratio between heat pump and boiler power. A system of this type, considering a building renovation, has several other advantages: easy installation, smaller dimensions and lower costs for adapting the electric power supply line. Remaining in the context of 
multi-dwelling buildings, even in the case of comparison with heat pump-only installations, the hybrid system is the winner for the significant reduction in investment, the advantage of the redundancy of the generators and for the improvement of the heat pump efficiency at partial loads, ensuring a more regular operation of the compressors even at low speeds.

We strongly believe that to achieve the requirements set by the European Union it is necessary to progressively improve the entire building system, improving both the envelope and the existing thermal plants.

\section{References}

1. ISTAT, Edifici e Abitazioni (August 2014)

2. LEAP, Efficienza energetica ed impatto ambientale degli impianti termici, autonomi e centralizzati, nel contesto normativo nazionale e regionale, pp. 80-83 (October 2009)

3. Regione Emilia-Romagna - Servizio Energia, Indicazioni metodologiche per l'applicazione dei fattori di conversione al metodo di calcolo di cui alla DGR 967/2015 e alla DGR 1275/2015 (September 2015)

4. UNI/TS 11300-2, Determinazione del fabbisogno di energia primaria e dei rendimenti per la climatizzazione invernale e per la produzione di acqua calda sanitaria (May 2018) 